\title{
Multistage evolution of oceanic upper mantle: Evidence from Lesveos ophiolitic peridotites, Greece
}

\author{
Yong Xu, JingAo LiU*, GuOChEn DONG, DONGXu Li \\ GPMR, China Univ. of Geosciences, Beijing 100083, China \\ *jingao@cugb.edu.cn
}

Ophiolites are relics of oceanic lithosphere and record some important processes during the growth and evolution of ocean. The Lesvos ophiolitic massif, located in the NE Aegean Sea, is dominated by ultramafic mantle rocks. Previous views have long thought that the Lesvos ophiolites were part of the Neo-Tethyan Oceanic lithosphere [1], but some recent studies have argued that they were formed in an incipient continental rift [2]. To further study the origin of the Lesvos ophiolites, we utilized highly siderophile element (HSE) abundances and Re-Os isotopes, in combination with petrology, bulk-rock major and trace element compositions, to study 14 ophiolitic mantle peridotites (including 6 lherzolites and 8 harzburgites) from Lesvos Island, Greece. The harzburgites are more refractory with higher degrees of partial melting (F: 15-25\%) than the more fertile lherzolites (F: $\leq 15 \%$ ). The chondrite-normalized HSE patterns of the harzburgites are more varible (e.g., $(\mathrm{Pd} / \mathrm{Ir})_{\mathrm{N}}$ : 0.69-1.59), while those of the lherzolites $\left((\mathrm{Pd} / \mathrm{Ir})_{\mathrm{N}}\right.$ : 1.19-1.61, except one phlogopite-bearing peridotite with 2.11) are nearly flat as that of Primitive Upper Mantle. In the diagram of $(\mathrm{Pd} / \mathrm{Ir})_{\mathrm{N}}$ vs. $\mathrm{Al}_{2} \mathrm{O}_{3}$, although most samples plot along one fractional melting trend with $\mathrm{D}^{\mathrm{Pd}}$ sulfide/silicate $=10^{4}$, this partition coefficent value is so high that the model cannot match typical massif mantle residues. Instead, the sulfide-rich melt metasomatism after melt extraction can explain the elevated $(\mathrm{Pd} / \mathrm{Ir})_{\mathrm{N}}$ of the Lesvos peridotites. Their ${ }^{187} \mathrm{Os} /{ }^{188} \mathrm{Os}$ ratios (0.12193-0.12706) are mostly within the range of abyssal peridotites, except for one very depleted sample $(0.11695$ with $\mathrm{T}_{\mathrm{RD}}=1.6 \mathrm{Ga}$ ) which might be derived from part of recycled ancient continental lithosphere. The coexistence of oceanic lithosphere and ancient fragments is similar to other ophiolites along the Tethys realm, and their mutual peak TRD age ( $250 \mathrm{Ma})$ may represent one global melting event which formed the Neo-Tethyan ocean basin. Overall, the Lesvos ophiolitic peridotites reveal at least two-stage processes from the continental rifting (melt extraction) to the oceanic spreading (melt infiltration), and this multi-stage evolution is indeed an important reponse to the Wilson Cycle.

[1] Robertson, 2002. Lithos 65, 1-67.

[2] Koglin et al., 2009. Lithos 108, 243-261. 